\title{
Palaeobotanical evidence for warm summers in the East Siberian Arctic during the last cold stage
}

\author{
Frank Kienast $^{\mathrm{a}, *}$, Lutz Schirrmeister ${ }^{\mathrm{a}}$, Christine Siegert $^{\mathrm{a}}$, Pavel Tarasov ${ }^{\mathrm{b}}$ \\ a Alfred Wegener Institute for Polar and Marine Research, Telegrafenberg A43, 14473 Potsdam, Germany \\ ${ }^{\mathrm{b}}$ Free University Berlin, Institute of Geological Sciences, Palaeontological Branch, Malteserstr. 74-100, Building D, 12249 Berlin, Germany
}

Received 30 April 2004

Available online 17 February 2005

\begin{abstract}
Plant macrofossils from the "Mamontovy Khayata" permafrost sequence $\left(71^{\circ} 60^{\prime} \mathrm{N}, 129^{\circ} 25^{\prime} \mathrm{E}\right)$ on the Bykovsky Peninsula reflect climate and plant biodiversity in west Beringia during the last cold stage. $70 \mathrm{AMS}$ and 20 conventional ${ }^{14} \mathrm{C}$ dates suggest sediment accumulation between about 60,000 and $7500{ }^{14} \mathrm{C}$ yr B.P. The plant remains prove that during the last cold-stage arctic species (Minuartia arctica, Draba spp., Kobresia myosuroides) coexisted with aquatic (Potamogeton vaginatus, Callitriche hermaphroditica), littoral (Ranunculus reptans, Rumex maritimus), meadow (Hordeum brevisubulatum, Puccinellia tenuiflora) and steppe taxa (Alyssum obovatum, Silene repens, Koeleria cristata, Linum perenne). The reconstructed vegetation composition is similar to modern vegetation mosaics in central and northeast Yakutian relict steppe areas. Thus, productive meadow and steppe communities played an important role in the Siberian Arctic vegetation during the late Pleistocene and could have served as food resource for large populations of herbivores. The floristic composition reflects an extremely continental, arid climate with winters colder and summers distinctly warmer than at present. Holocene macrofossil assemblages indicate a successive paludification possibly connected with marine transgression, increased oceanic influence and atmospheric humidity. Although some steppe taxa were still present in the early Holocene, they disappeared completely before $\sim 2900{ }^{14} \mathrm{C}$ yr B.P.
\end{abstract}

(C) 2005 University of Washington. All rights reserved.

Keywords: Plant macrofossils; Arctic Siberia; Palaeoclimate; Late Pleistocene; Vegetation

\section{Introduction}

The world's broadest shelves, with depths less than 100 m, occur between the Taymyr Peninsula and Alaska (Fig. 1). Due to Pleistocene marine regressions (Clark and Mix, 2002; Lambeck and Chappell, 2001), the now-submerged shelf areas were part of a huge arctic landmass named Beringia between the Lena and Mackenzie rivers (Hulten, 1937).

Beringia is considered a key region in the understanding of Cenozoic palaeoecology (Hulten, 1937). In contrast to other Arctic regions, the northeast Siberian and northwest American lowlands remained non-glaciated during the last

\footnotetext{
* Corresponding author. Fax: +49 3312882137.

E-mail address: fkienast@awi-potsdam.de (F. Kienast).
}

cold stage (Clark et al., 1993; Schirrmeister et al., 2002a; Siegert et al., 2002; Svendsen et al., 1999, 2004) and were covered with rather rich vegetation (Andreev et al., 2002; Elias et al., 1997; Goetcheus and Birks, 2001) that supported large populations of herbivores (Guthrie, 1990; Schirrmeister et al., 2002a; Sulerzhitsky and Romanenko, 1997; Vartanyan et al., 1993). Beringia was the major glacial refuge of arctic plants (Abott and Brochmann, 2003; Hulten, 1937; Nimis et al., 1998). The land bridge facilitated species exchange between Eurasia and North America (Hulten, 1937) until the opening of the Bering Strait about 5 myr ago (Marincovich and Gladenkov, 1999) and periodically thereafter during glacial sea-level regressions.

The character of environment prevailing in Beringia during the Pleistocene is controversial. Numerous bones of large grazers like mammoth, bison, horse and wooly rhinoceros, outcropping from permafrost deposits along 

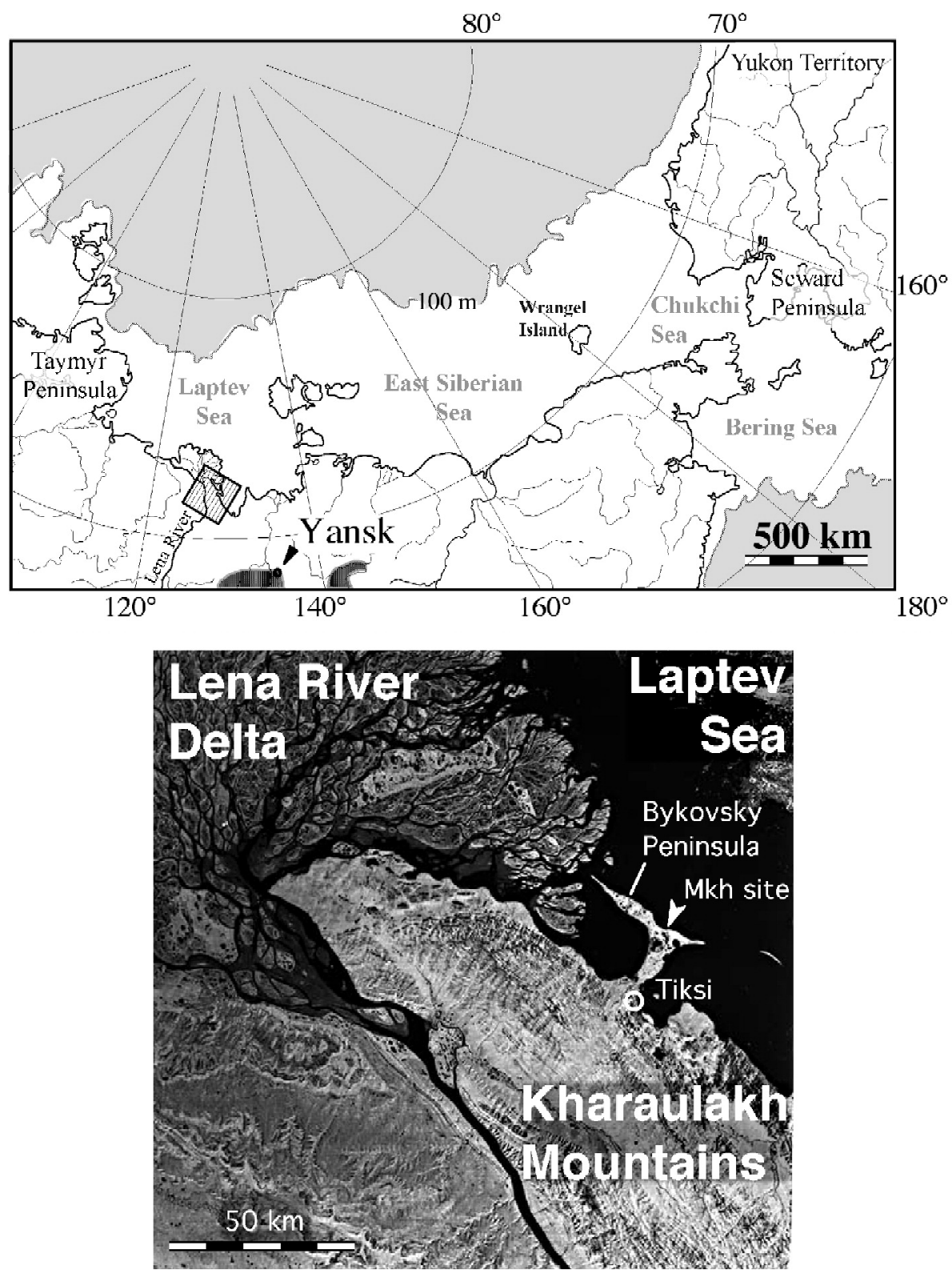

Figure 1. Location of the Mamontovy Khayata site and of the meteorological stations Tiksi and Yansk with respect to the modern shoreline and to the 100-m isobath, which indicates the mean extent of the continent during the last cold stage. The dark-shaded signature shows the most important extrazonal distribution areas of steppe vegetation in Northeast Yakutia (after Yurtsev). Satellite image available at: http://www.daac.gsfc.nasa.gov/DAAC_DOCS/geomorphology/ GEO_HOME_PAGE.html.

the arctic coasts and riverbanks (Guthrie, 1990; Kuznetsova et al., 2003; Orlova et al., 2000; Pitulko et al., 2004; Schirrmeister et al., 2002a; Sulerzhitsky and Romanenko, 1997), suggest that during the cold stages the exposed landmass between the Old and New Worlds must have been covered by productive steppe-like vegetation (Guthrie, 1990, 2001; Nehring, 1890; Tugarinov, 1929). This presumption is supported by disjunct arctic and subarctic steppe plant occurrences, which are considered to be relicts of a formerly closed and more northerly extended distribution area of those species (Andreev and Galaktionova, 1981; Yurtsev, 1982, 2001). In addition, the analogies of arctic cold-stage pollen spectra and modern surface pollen samples from relict steppe occurrences in Greenland (Böcher, 1954) and on Wrangel Island (Yurtsev, 1982) indicate steppe-like palaeoenvironments (Iversen, 1973; Yurtsev, 1982).

The climate during the last cold stage of the northern Siberian lowlands has been generally thought to be colder than present throughout the year, with a mean July temperature close to $0^{\circ} \mathrm{C}$ (Frenzel et al., 1992; Velichko, 1984). The low pollen concentrations and the absence of local tree and shrub taxa in last cold-stage sediments have been taken as evidence of severe climate and of sparse and low-productive vegetation, similar to the present arctic desert (Cwynar and Ritchie, 1980; Kozhevnikov and Ukraintseva, 1997; Ritchie, 1984). Climate modelling supports this interpretation and 
indicates LGM temperatures across northern Eurasia lower than present, because of continental glaciation and decreased summer insolation (Clark et al., 1999; Kageyama et al., 2001; Kutzbach et al., 1993).

The controversy-productive steppe or sparse arctic desert-remained unsettled because macropalaeobotanical evidence of steppe plants in the arctic lowlands during the glacial epoch was missing (Yurtsev, 1982). Anderson et al. (1994) and Birks and Birks (2000) highlighted the limitations of palynological methods for the reconstruction of the arctic palaeovegetation, as a result of very low local pollen production of most arctic species. Moreover, most herbaceous plants cannot be identified to the species or even the genus level. In contrast, fossil leaves, seeds and fruits can often be precisely identified. Studies of plant DNA fragments in bulk samples from Pleistocene permafrost (Willerslev et al., 2003) resulted in a taxonomical resolution until now no better than achieved by pollen analysis. This approach has, however, a great potential if applied for unidentifiable macrofossils.

In Beringia, cold-stage plant macrofossils were studied from sediments of the shelves of the Bering and Chukchi seas (Elias et al., 1997) and, most spectacular, from an in situ tephra-buried land surface on the Seward Peninsula (Goetcheus and Birks, 2001). None of the records from central Beringia contained remains of steppe taxa that could indicate the former existence of a mammoth steppe (Guthrie, 1990), although indicators of rather dry habitats were found. Beyond the limits of the Beringian lowlands, steppe plants were identified very sporadically on the Taymyr Peninsula (Kienast et al., 2001) and in the Yukon Territory (Zazula et al., 2003). Both records are, however, far from the formerly exposed Beringian shelf. Located in mountainous regions, they might reflect local palaeoenvir- onmental conditions and thus might not be representative of the Beringian palaeovegetation.

In this paper, we describe in detail the local vegetation that occurred at the Bykovsky Peninsula $\left(71^{\circ} 60^{\prime} \mathrm{N}, 129^{\circ} 25^{\prime} \mathrm{E}\right.$, [Fig. 1]) during several time segments from the last cold stage and the Holocene. The reconstruction is based on the analysis of plant macrofossils from the permafrost sequence "Mamontovy Khayata" (Yakutian: "Mammoth hill," hereafter Mkh). The implications for climate and biodiversity of the westernmost Beringian lowlands are discussed.

\section{Study area}

The Bykovsky Peninsula is situated at the Laptev Sea coast south-east of the Lena River delta in the foreland of the Kharaulakh mountain range (Fig. 1). In consequence of its position at the western margin of the Ust-Lena Rift, intense seismic activities, mainly vertical block tectonics, characterize this region (Drachev et al., 1998). Forming the foothills of the Verkhoyansk mountain range, the Kharaulakh Range elevates up to $1000 \mathrm{~m}$.

The Bykovsky Peninsula represents the remnants of a late Pleistocene accumulation plain (Siegert et al., 2002). The highest elevations of the Bykovsky Peninsula, about 40 $\mathrm{m}$ high, are composed of Ice Complex sediments and represent the land surface during the last cold stage. "Ice Complex" stands for very ice-rich and perennially frozen fine-grained deposits, penetrated by thick polygonal icewedge systems (Fig. 2) and formed under extremely continental climate in terrestrial accumulation plains, mainly in the lowlands and river valleys of north Siberia during the cold stages of the late Pleistocene (Schirrmeister et al., 2002b; Siegert et al., 2002).

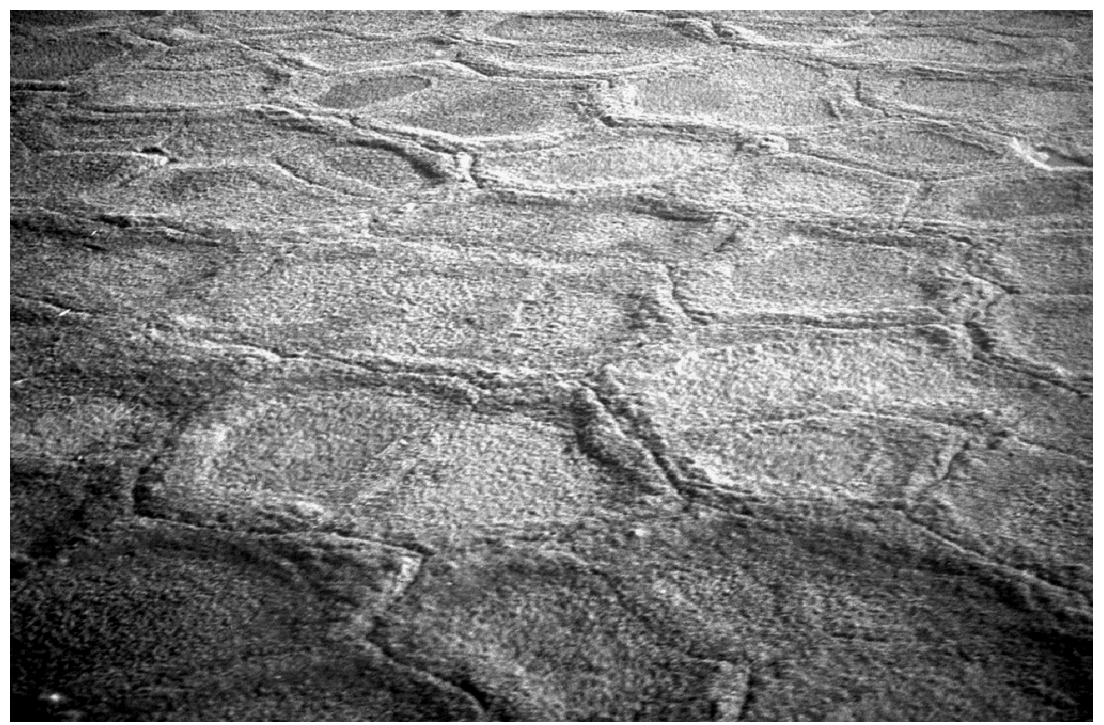

Figure 2. Polygonal surface in the tundra of the recent Lena River Delta as a result of netlike distributed ice wedge systems underneath. Similar structures occurred at the exposed Laptev Sea shelf during the last cold stage. Photo: L. Kutzbach. 
The permafrost in the study area occurs continuously and penetrates up to 500-650 $\mathrm{m}$ in depth (Grigoriev, 1993). At the zone of zero annual amplitude, the permafrost temperature is between -8 and $-13^{\circ} \mathrm{C}$ (Grigoriev, 1993). Due to the position of the Bykovsky Peninsula in a zone of subsidence, the constitutive Ice Complex is very thick (Ivanov and Katasonova, 1978). Numerous thermokarst depressions and thermoerosional channels as a result of intense permafrost degradation characterize the modern geomorphology of the Bykovsky Peninsula.

Modern temperatures vary from $7^{\circ} \mathrm{C}$ in July to $-30^{\circ} \mathrm{C}$ in January. The mean annual temperature is $-12^{\circ} \mathrm{C}$ (http://www.washingtonpost.com/wp-srv/weather/longterm/ historical/data/tiksi_russia.htm). Although mean annual precipitation is only $190 \mathrm{~mm}$, the climate is humid due to low evaporation. The climatic humidity is reflected by zonal soils, mainly gelic gleysols and gelic histosols (FAO-UNESCO, 1988).

According to the Circumpolar Arctic Vegetation map (CAVM Team, 2003), the vegetation on the peninsula is graminoid tundra, more precisely nontussock sedge, dwarf shrub, moss tundra. In polygonal mires and in thermokarst depressions, it consists mainly of wetland communities dominated by Eriophorum vaginatum, E. scheuchzeri, Carex ensifolia ssp. arctisibrica and C. aquatilis. At the raised, well-drained polygon borders, Betula exilis, Salix pulchra, S. glauca, Ledum decumbens, Vaccinium vitisidaea and V. uliginosum ssp. microphyllum occur. The dominating plants are characteristic species of the formal vegetation units (syntaxa) Oxococco-Sphagnetea Br.Bl. and Tx. 1943 and Scheuchzerio-Caricitea nigrae Nordh. 1936, which thus can be considered as representative of the Bykovsky Peninsula.

Site Mkh is noted for the finding of thousands of late Pleistocene mammal bones and large quantities of mammoth ivory (Kuznetsova et al., 2003; Schirrmeister et al., 2002a), including the first described mammoth carcass ever (Adams, 1807), and is a key site of the reconstruction of late Pleistocene environments in the Siberian Arctic. Multidisciplinary work included comprehensive age determinations (Schirrmeister et al., 2002b), cryolithological and sedimentological studies (Schirrmeister et al., 2002b; Siegert et al., 2002), isotope analyses on groundice (Meyer et al., 2002), studies of insects (Kuzmina, 2001), pollen (Andreev et al., 2002), mammals (Kuznetsova et al., 2003), testate amoebae (Bobrov et al., 2004) and ostracodes (Wetterich et al., submitted for publication).

\section{Material}

Exposed at the Laptev Sea coast, the Ice Complex of the Bykovsky Peninsula was made accessible by coastal erosion and wave action. The Mkh site is a cliff rising to $40 \mathrm{~m}$ a.s.l. and is composed of numerous subprofiles, so-called thermokarst mounds (Fig. 3). Several of these laminated sediment blocks, which consist of calcareous silty sands interbedding with organic-rich layers and horizons of palaeosoils with fine grass roots (Fig. 4) have been studied.

Reworking and redeposition of material may strongly affect results and interpretation of palaeoenvironmental reconstructions. Siegert et al. (2002) and Schirrmeister et al. (2002b) published results of sedimentological, mineralogical and geomorphological studies of the Mkh sequence with special attention to the redeposition problem. Grain size distribution and heavy mineral composition indicate that the Mkh deposits are of local origin, and that their transport by the Lena River can consequently be excluded (Siegert et al., 2002). In fact, the neighboring ridges of the Kharaulakh Mountains acted as main source area for the sediments of the Mkh sequence (Siegert et al., 2002). The sedimentological and cryolithological structure of the

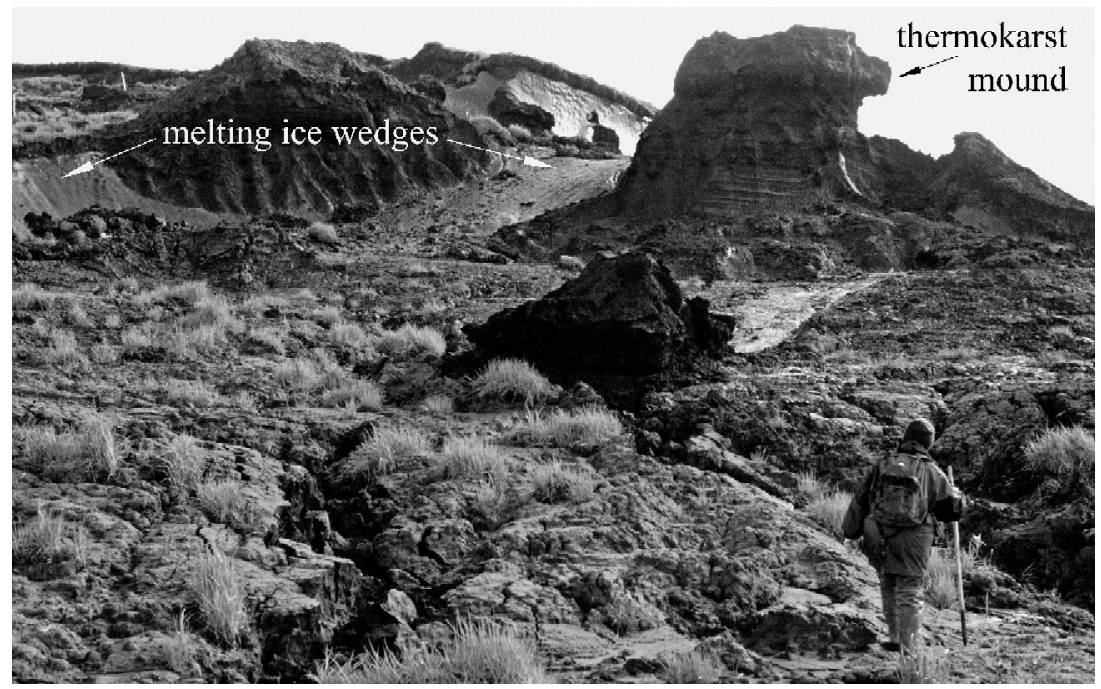

Figure 3. Subprofiles of the sequence Mamontovy Khayata. The thermokarst mounds arose after ice wedge melting in the course of thermoerosion of the Ice Complex. Photo: H. Meyer. 


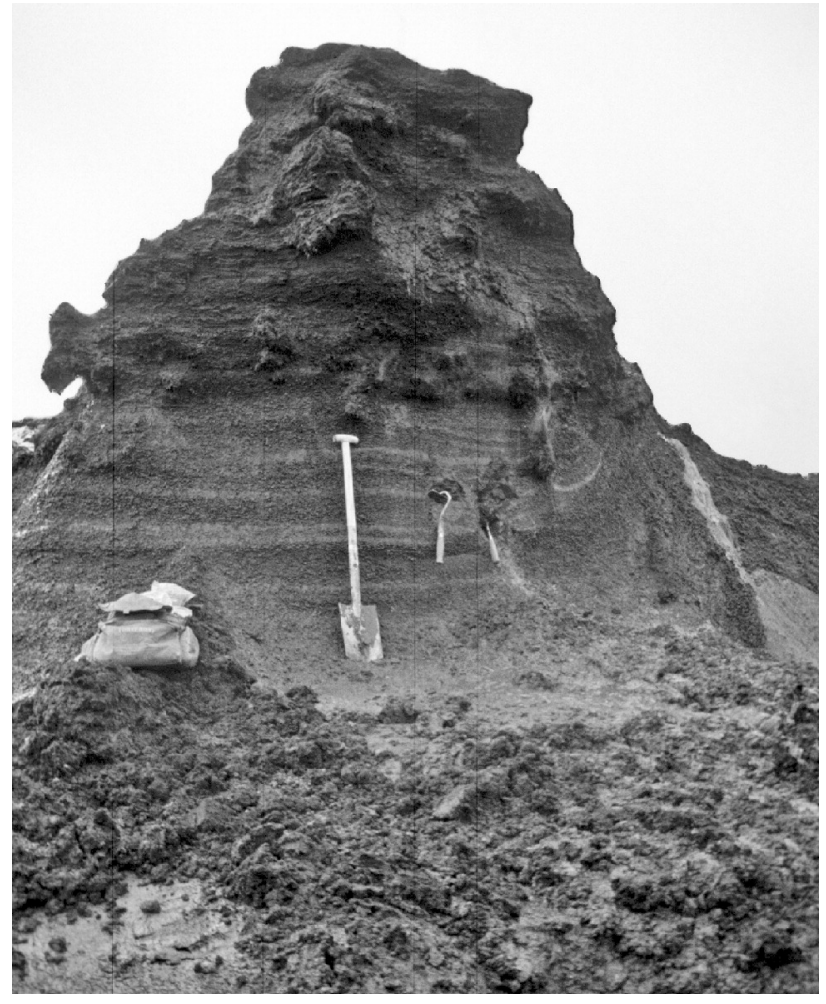

Figure 4. One of the sampled thermokarst mounds. The sediment structure is not disturbed by thermoerosion. Photo: L. Schirrmeister.

sequence is described in detail in Schirrmeister et al. (2002b).

Ice Complex deposits were subaerially exposed and transferred into permafrost quasi synchronously with their accumulation. They are rich in well-preserved plant macrofossils, which were used as bioindicators in the present study. Frequency and intensity of storms are assumed to have been highly decreased under extremely continental cold-stage conditions due to northward extension of the stable Siberian-Mongolian high pressure system, connected with the exposition of north Siberian shelves (Borisov, 1965). Therefore, seeds and fruits were transported presumably not very far and rather by melting water than by wind. The Bykovsky Peninsula is considered as rest of a proluvial fan consisting of material, transported from the hill country at the foot of the Kharaulakh Range by seasonally active rivers (Siegert et al., 2002). Thus, we assume that the taxonomic composition of the fossil seed bank in the Ice Complex reflects the local palaeovegetation at the lowland of today's Bykovsky Peninsula and, partly, of the Kharaulakh foreland.

\section{Methods}

\section{Sampling and preparation in the lab}

Between 1 and 15 liters of frozen material per sample, depending on accessibility, was taken for plant macrofossil analysis from several thermokarst mounds, covering the whole Ice Complex sequence. Additionally, Holocene deposits on the top of the Ice Complex and from an adjacent thermokarst depression ("alas") were sampled in order to detect detailed features of the glacial and interglacial vegetation.

The samples were air-dried and most of them remained further untreated in the field. Some samples, however, were enriched in plant remains by removal of the fine mineral fraction by wet sieving through $0.2-\mathrm{mm}$ meshed fabric (Sher et al., 2000).

In the lab, the samples were suspended in water, wet sieved, using mesh sizes of 2, 1, 0.5 and $0.25 \mathrm{~mm}$, and dried at room temperature. For dispersion of organic aggregates, clotty sample parts were shortly exposed to diluted $\mathrm{H}_{2} \mathrm{O}_{2}$ $(1,5 \%$, less than $3 \mathrm{~min})$. When sediment and plant remains stick together very strongly, it is more gently to expose the sample to diluted $\mathrm{H}_{2} \mathrm{O}_{2}$ than to try to remove the minerals mechanically or by seething with $\mathrm{KOH} . \mathrm{H}_{2} \mathrm{O}_{2}$ firstly attacks dissolved organic compounds, which are the main adhesive agent in these aggregates. The resulting bubbling supports the gentle suspension of aggregate. We only used the method when the sample parts were strongly aggregated.

\section{Dating}

70 AMS and 20 conventional radiocarbon dates (see details in Schirrmeister et al., 2002a,b) suggest that the sediments of the Ice Complex sequence and the overlying Holocene peat accumulated without long breaks from about 60,000 to $7500{ }^{14} \mathrm{C}$ yr B.P. The age/height model (Fig. 5) shows that even dates more than $40,000{ }^{14} \mathrm{C}$ yr B.P. and

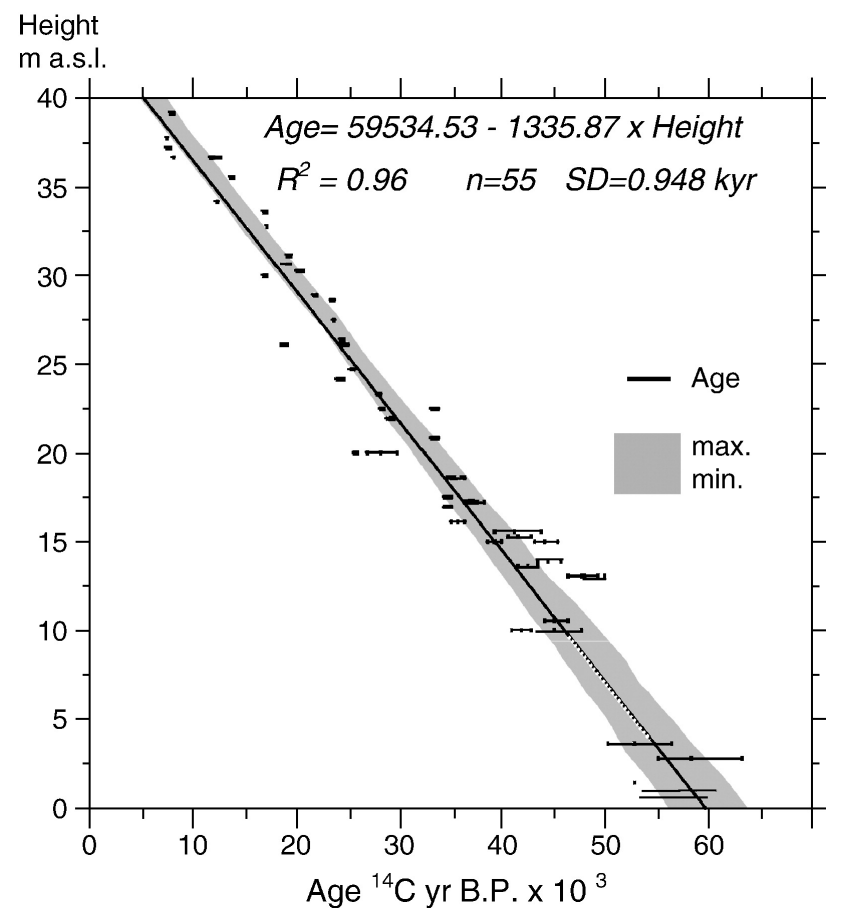

Figure 5. Age-height relation of the sequence Mamontovy Khayata. 
consequently exceeding the reliability limit of the radiocarbon method, fit very well into the extrapolated agealtitude relation. Accordingly, the sediments accumulated without great hiatus, thus quasi continuously. In contrast to lake sediments, permafrost deposits accumulate with low chronological resolution (between decades and centuries) due to cryoturbation processes in the active layer. We cannot exclude that a hiatus occurred within such a timeframe. But in the light of the exactness of radiocarbon dating, this is practically irrelevant. The additionally taken alas deposits are radiocarbon dated to $\sim 2900{ }^{14} \mathrm{C}$ yr B.P.

\section{Plant macrofossil identification}

Identifiable plant remains, namely seeds, fruits, and exceptionally leaves, were picked using a stereomicroscope. The identification of macroremains was based on the carpological reference collection of the Museum of Natural History at the Humboldt University, Berlin. In order to identify adequately potential steppe indicators, the authors upgraded the collection by several hundred new species from relic steppe sites in central and northeast Yakutia. In addition, some identification keys and atlases were used (Aalto, 1970; Anderberg, 1994; Beijerinck, 1947; Berggren, 1969, 1981; Cappers, 1993; Egorova, 1999; Jessen, 1955; Katz et al., 1965; Körber-Grohne, 1964).

\section{Reconstruction of palaeoenvironment}

The identified taxa were, as major step in the palaeoenvironmental reconstruction, associated with abstract plant communities (syntaxa) according to their present day main occurrences and ecology in the circumarctic tundra (Dierßen, 1996) and the central-Siberian (Daurian)-Mongolian steppe (Hilbig, 1995; Table 1). To be comparable with recent vegetation, the syntaxa follow the Braun-Blanquet nomenclature (Weber et al., 2000). The most characteristic macrofossil taxa are presented in Figure 6.

The ecological niche of a community is more restricted than that of its components (Birks and Birks, 1980). Consequently, the reconstructed syntaxa, labeled by characteristic species, indicate the former local habitat conditions and dependence on topography better than individual species. Moreover, it can be assumed that characteristic species of the reconstructed plant communities probably were present in the palaeovegetation, even though their remains were preserved insufficiently for identification. This is true e.g., for Artemisia, an important component of the Mkh pollen spectra according to Andreev et al. (2002). For community reconstruction, only the presence or absence of a plant taxon was considered. Quantities of plant remains remained unconsidered since sample volumes were not comparable due to the diversity of sample textures (sand, silt, peat, etc.) and unequal sample treatment in the field. Moreover, plants produce variable numbers of seeds and fruits. Quantities of fossil seeds, which were the most frequently found macroremains in the present study, are hence not comparable between different plant species (Birks and Birks, 1980). Also, the effects of inhomogeneous preservation or decomposition, respectively, can be attenuated by this approach. Likewise, modern plant communities are defined in terms of their taxonomical composition independent on single species abundances. The reconstruction of syntaxa was carried out at class level, because the incompleteness of the fossil species spectra complicated a finer syntaxonomical resolution.

\section{Results and interpretation}

The composition of late Pleistocene species differed considerably from Holocene ones, although certain "Pleistocene" plants such as boreal aquatics and even steppe species are present in the early Holocene sample, dated to about $7800{ }^{14} \mathrm{C}$ yr B.P. (Fig. 7). Therefore, we distinguished Holocene and Pleistocene vegetation complexes, which are separately described following in the order of their topographical occurrence (Fig. 7), beginning with water-filled depressions.

\section{The vegetation complex of the last cold stage}

\section{Boreal aquatics}

(Potamogetonetea pectinati R. TX. and PRSG. 1942.)

Fruits of Hippuris vulgaris, Batrachium and abundant macrofossils of Callitriche hermaphroditica and Potamogeton vaginatus were found. All identified aquatics are distributed mainly in the boreal or temperate zones (Dierßen, 1996; Meusel et al., 1978) and are first colonizers in shallow lakes and ponds (Elias et al., 1997), often with brackish or slightly saline water (Dierßen, 1996; Glück, 1936). C. hermaphroditica and $P$. vaginatus require warm summer conditions and do not occur north of the $12^{\circ} \mathrm{C}$ mean July isotherm today (Krasnoborov, 1988; Meusel et al., 1978).

\section{Littoral pioneer vegetation}

(Bidentetea tripartae R. TX. ET AL AP. R. TX. 1950, Littorelletea BR. BL. and TX. 1943 EX WESTH. ET AL. 1946, Cakilitea maritimae R. TX. and PRSG. 1950.)

The abovementioned classes were treated in combination, because they are not clearly differentiated sociologically and the recent floristic differences between them are indistinct especially in arid regions of north Asia and under salt influence (Dierßen, 1996; Hilbig, 1995). Littoral pioneer communities are represented by Ranunculus reptans, Senecio congestus, Rumex maritimus, Chenopodium glaucum and Stellaria crassifolia. These species colonize moist, bare, erosive soils in the range of fluctuating water levels at shores of shallow lakes and regularly inundated depressions (Dierßen, 1996; Hilbig, 1995). We consider a succession of certain species along specific sections of the littoral. For example, $R$. reptans can grow on 
both submerged and emerged soils, but is preferably adapted to water-logged emerged soils. That species is characteristic of oligotrophic water and endures salt concentrations up to 6 \%o (Dierßen, 1996). Probably, it grew closest to the water line and fell dry last. The halophytes $R$. maritimus, Chenopodium glaucum and S. crassifolia are indicative of salty and nutrient-rich littoral habitats, and thus occurred farther from the water at drier, saltier and more eutrophic places.

\section{Floodplain meadows}

(Asteretea tripolii WeSTHOFF ET BEEFTINK. 1965.)

Alkali grass (Puccinellia tenuiflora) and the wild barley (Hordeum brevisubulatum) are characteristic meadow grasses of closed topographic depressions (alases) with a strongly fluctuating groundwater table and salt accumulation ("saltpans") in central Yakutia (Mirkin et al., 1985). Their main distribution area is, however, Mongolia, where they compose floodplain meadows along rivers, around lakes and in topographic depressions (Hilbig, 1995). Both species are salt tolerant. Although occurring exclusively under arid climates, the community is, due to favorable groundwater availability at the floodplains, a highly productive pasture.

\section{Steppe communities}

(Festuco-Brometea BR.-BL. and TX. 1943, KoelerioCorynephorethea KLIKA AP. KLIKA and NOWÁK 1941.)

The macrofossil finds of steppe plants in the arctic permafrost sequence Mamontovy Khayata are evidence of the contentious former existence of steppe vegetation in Beringia. Of the dicots, Alyssum obovatum, Silene repens, Myosotis alpestris, Rumex acetosella, Potentilla stipularis and $P$. arenosa were identified. They are characteristic for Daurian-Mongolian mountain steppes (Hilbig, 1995). Remains of the grasses Koeleria cristata, Festuca sp. and Poa sp. have also been found. Festuca lenensis, F. sibirica and species of the Poa section Stenopoa are characteristic elements of Mongolian steppes (Hilbig, 1995) and relic steppe communities in northeastern Siberia (Yurtsev, 2001). Moreover, K. cristata, Androsace septentrionalis and Linum perenne are steppe indicators with a circumpolar distribution. A singular fruit of Thesium was found in the sample dated to about $48,000{ }^{14} \mathrm{C}$ yr B.P. Its modern closest distribution area is central Yakutia (Meusel et al., 1978), where mean July temperatures exceed $15^{\circ} \mathrm{C}$. Numerous finds of fruits of Carex duriuscula in Mkh sediments are noteworthy, as this plant indicates overgrazing or trampling in steppe and floodplain meadow communities (Hilbig, 1995).

\section{Arctic/Alpine pioneer vegetation}

(Thlaspitea rotundifoliae BR. BL. 1948) and Kobresia meadows (Carici rupestris-Kobresietea OHBA 1974.)

Arctic/Alpine pioneer vegetation and Kobresia meadows were treated together because of their similar floristic composition and ecology, and their connection in the successional series. They correspond to the herbaceous cryoxerophyte vegetation, described by Yurtsev (2001) for the vegetation mosaic of Beringia's tundra-steppe. In our record, arctic pioneer communities are represented by Minuartia spp., Papaver sect. Scapiflora, Draba spp., Cerastium spp., Stellaria spp. and Saxifraga spp., each taxon including several species. Arctic pioneer communities form the northernmost vascular plants in polar deserts. They occupy well-drained sites, disturbed by deflation in winter due to lack of snow cover (Dierßen, 1996). Kobresia meadows replace arctic pioneer communities after substrate stabilization (Dierßen, 1996). They are considered as important components of the zonal vegetation of Beringia during the cold stages of the Pleistocene (Walker et al., 1991, 2001; Yurtsev, 2001). In the Mkhrecord, Kobresia myosuroides, Potentilla nivea and Thalictrum alpinum were identified among others. Some taxa, e.g., Minuartia arctica, Potentilla hyparctica, Saxifraga spinulosa, Draba spp. and Stellaria spp. appear in both communities. All species are extremely frost resistant and adapted to strong seasonal temperature fluctuations (Dierßen, 1996).

\section{Holocene vegetation}

\section{Wetland vegetation}

(Scheuchzerio-Caricetea nigrae (NORDH. 1936) R. TX. 1937, Oxycocco-Sphagnetea BR. BL. and TX. 1943.)

The floristic composition of Holocene macrofossil assemblages, dominated by wetland communities with Carex aquatilis including the subsp. stans, Eriophorum scheuchzeri, E. vaginatum, Comarum palustre and Betula exilis shows good correspondence to modern tundra vegetation in the study area and indicates a stable wet environment. Carex aquatilis, $C$. aquatilis ssp. stans, $C$. bigelowii ssp. arctisibirica and Eriophorum scheuchzeri are characteristic species of Scheuchzerio-Caricetea nigrae, occurring on wet mineral soils with slightly acidic to basic substrates (Dierßen, 1996), for instance in the centers of polygonal depressions (Fig. 2) or in thermokarst depressions.

Communities of the class Oxycocco-Sphagnetea are typical of moderately wet until periodically dry, rather acidic mires (Dierßen, 1996), such as the raised borders of polygons. They are represented in our macrofossil records by Eriophorum vaginatum, B. exilis, Saxifraga hirculus and Vaccinium uliginosum.

\section{Snow-bed vegetation}

(Salicitea herbaceae Br. B1. 1947.)

Plants occurring at snow accumulation sites, represented by Ranunculus nivalis and various species of the snow saxifrage group (Saxifraga nivalis, S. hieracifolia, $S$. foliolosa), were detected only in the late Holocene sample, apart from a single Saxifraga tenuis seed in a sample dated to about $22,000{ }^{14} \mathrm{C}$ yr B.P. (Fig. 7). They indicate thick 


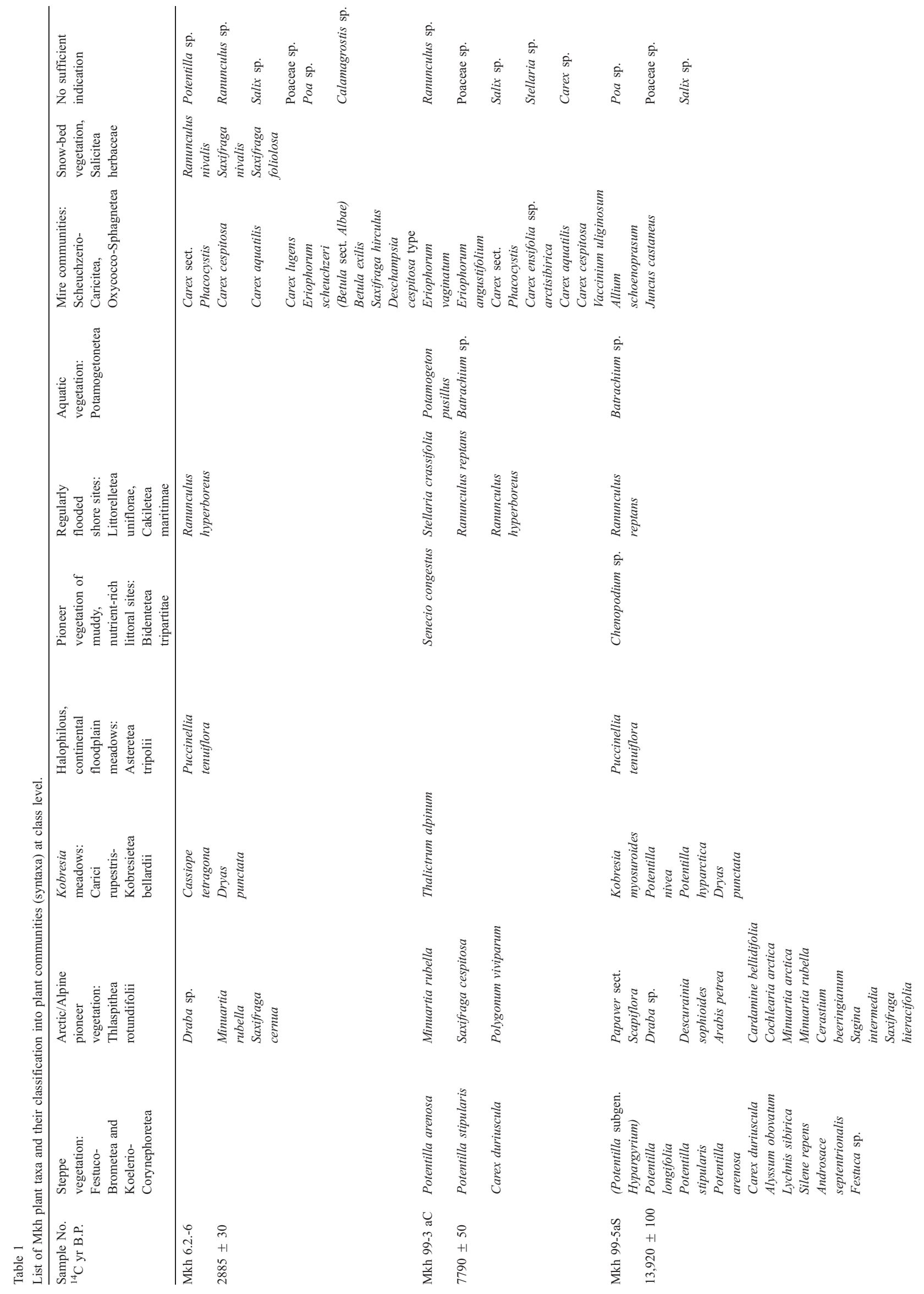




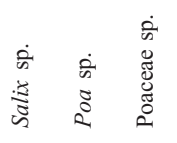

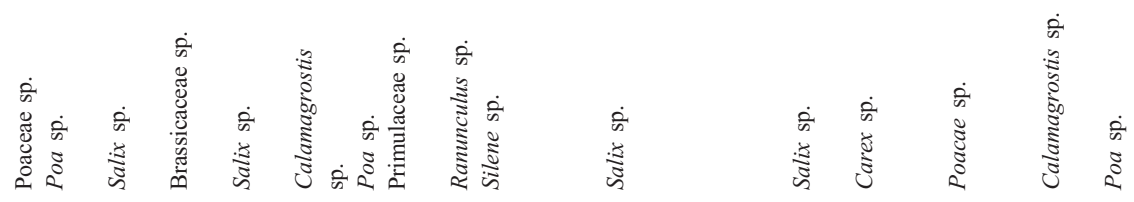

要

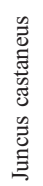

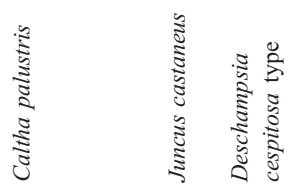

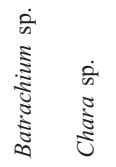

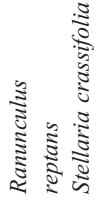

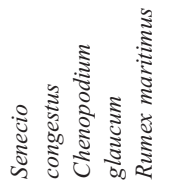

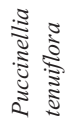

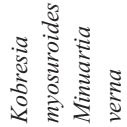

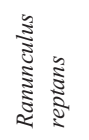

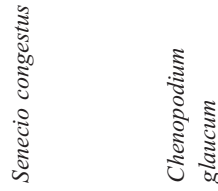

章

竎

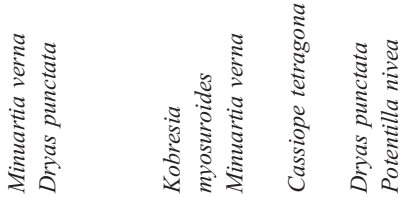

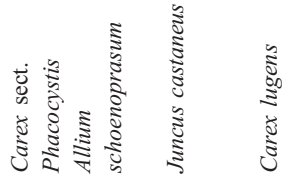

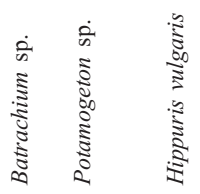

ปูำ

ב⿱艹

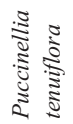

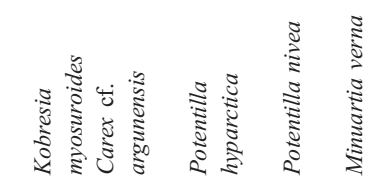

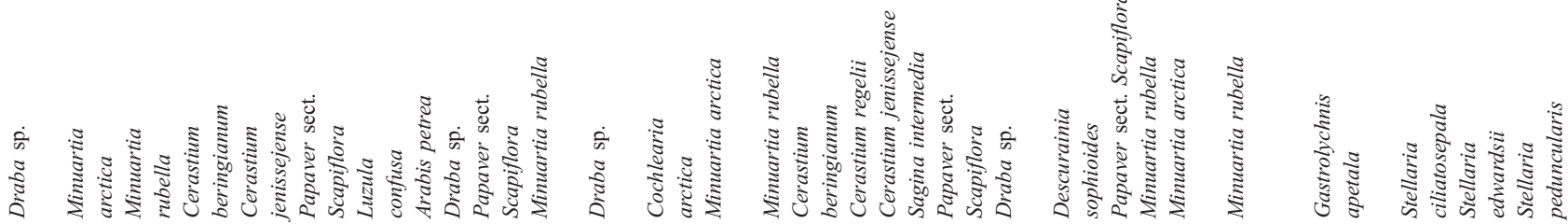

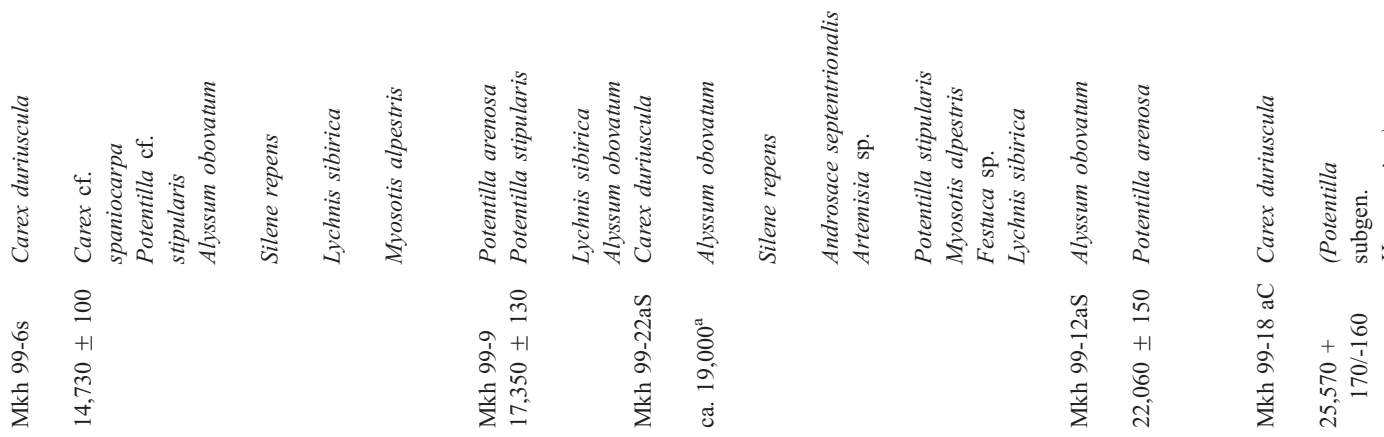




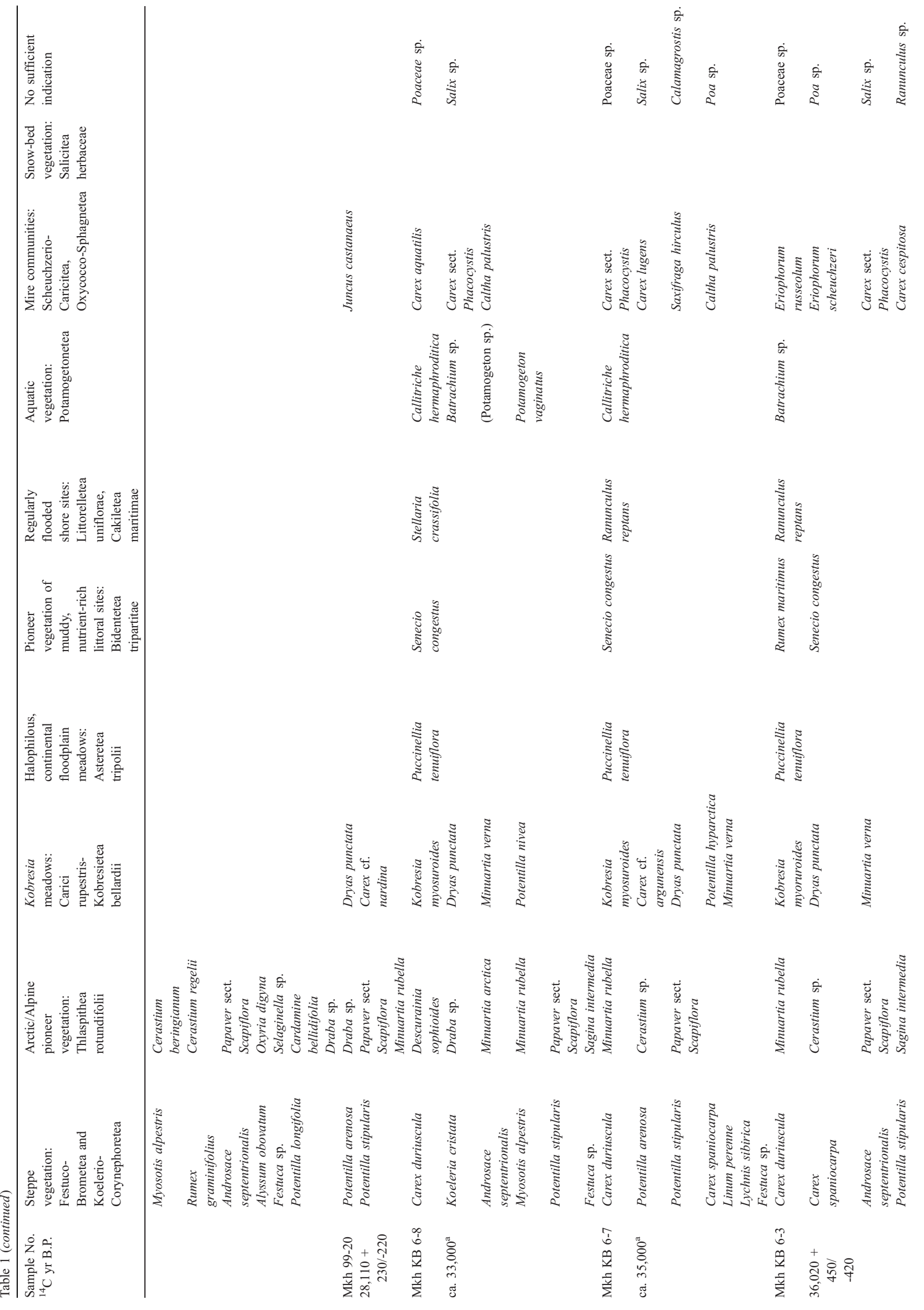




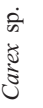

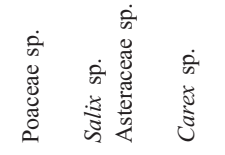

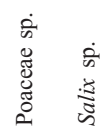

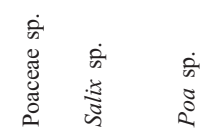

空

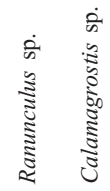

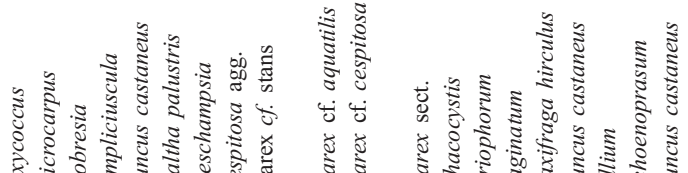

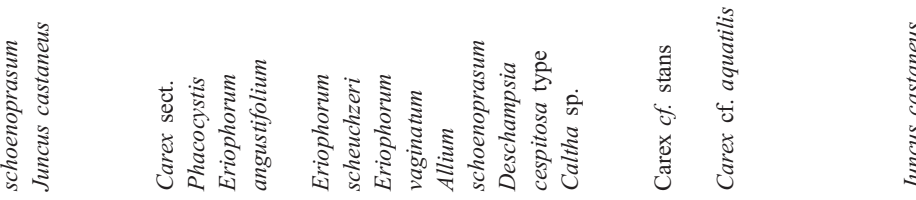

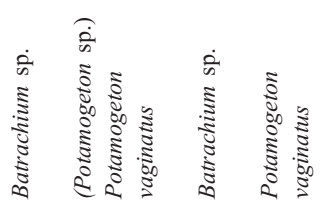
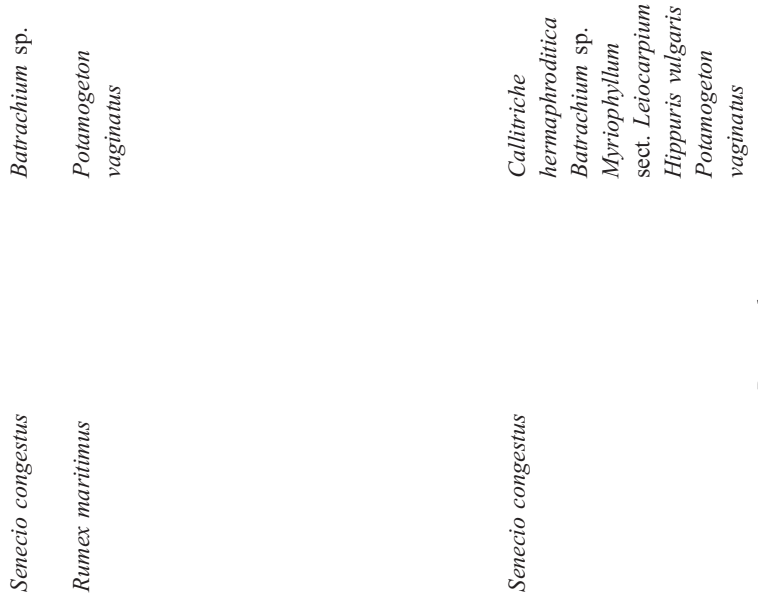

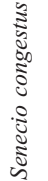

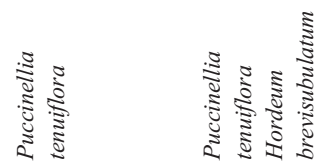

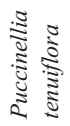

产

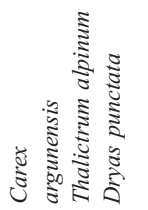

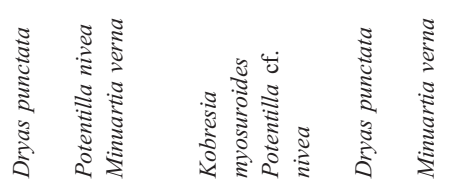

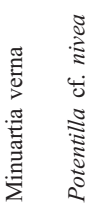

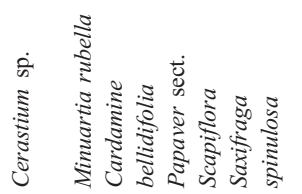

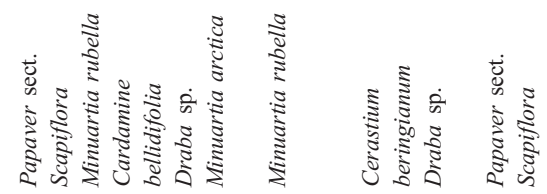

离

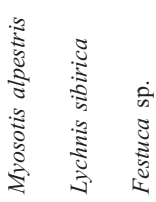

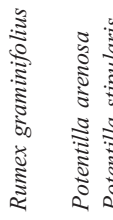

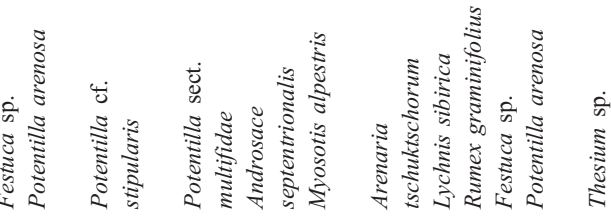

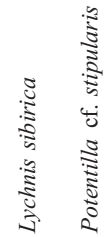

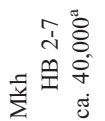

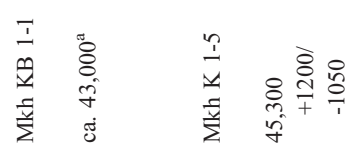

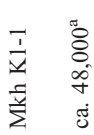

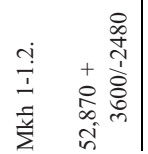




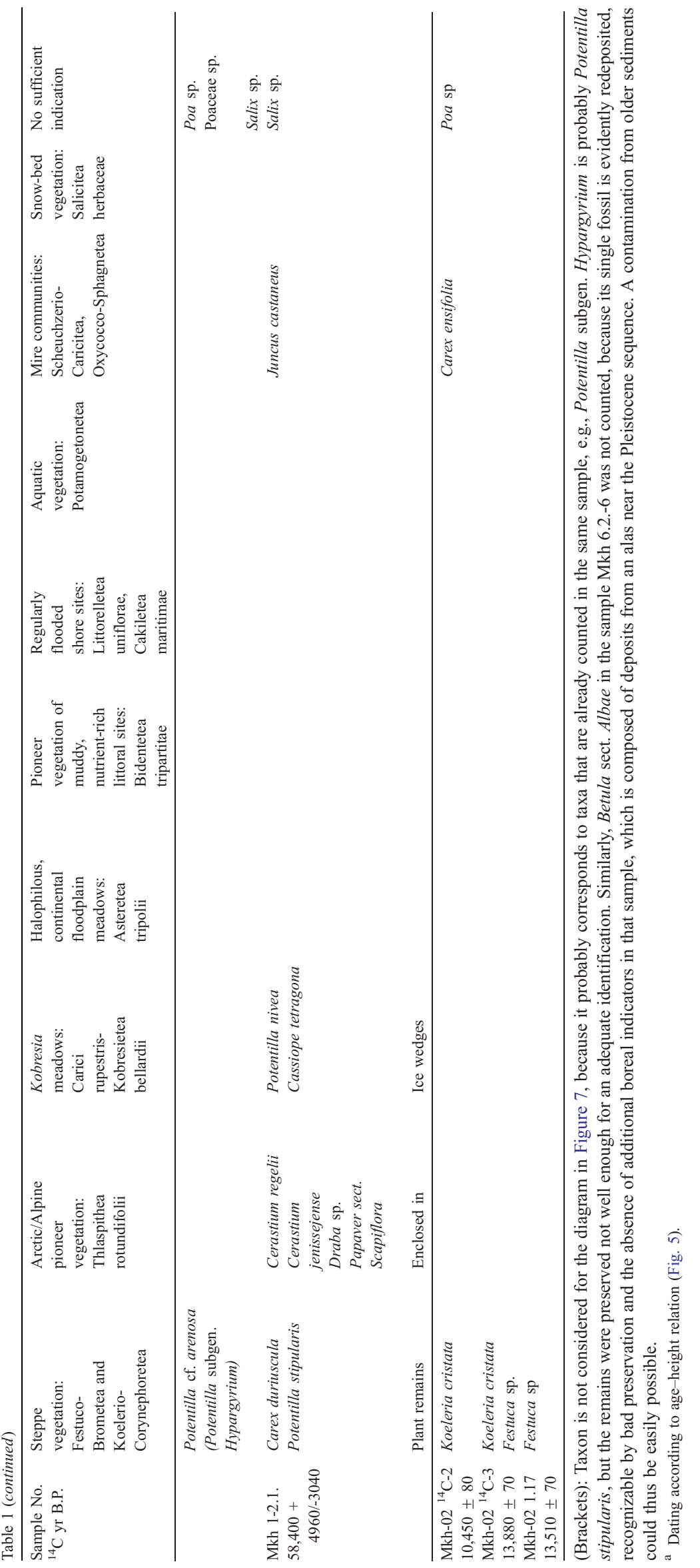




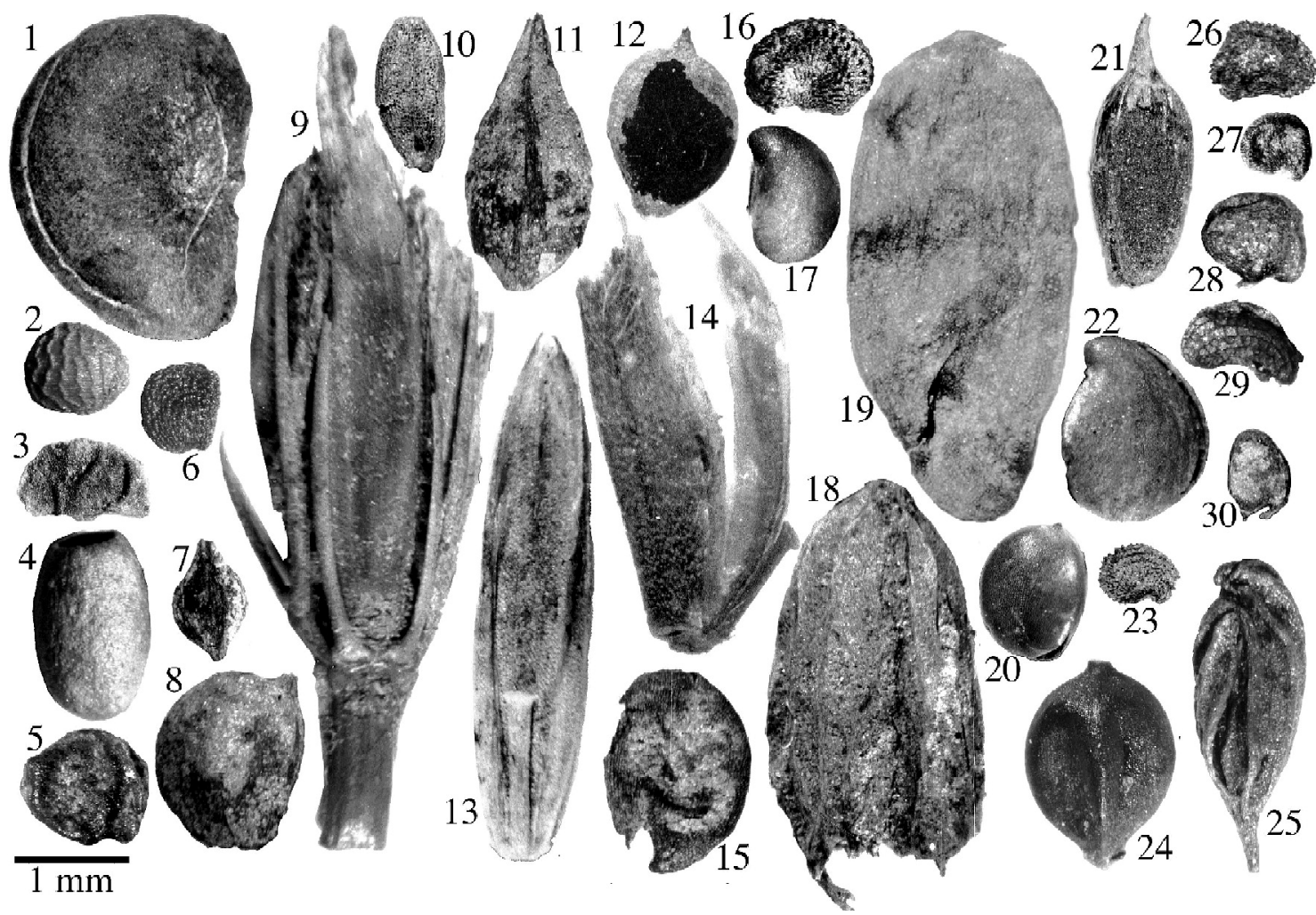

Figure 6. Plant macrofossils from the sequence Mamontovy Khayata representing the reconstructed syntaxa. Aquatic vegetation: (1) $P$. vaginatus; (2) Batrachium sp.; (3) C. hermaphroditica; (4) H. vulgaris. Littoral pioneer vegetation: (5) C. glaucum; (6) S. crassifolia; (7) R. maritimus; (8) R. reptans. Floodplain meadows: (9) H. brevisubulatum; (10) P. tenuiflora. Steppe communities: (11) C. duriuscula with utricle; (12) C. duriuscula without utricle; (13) Festuca sp.; (14) K. cristata; (15) A. obovatum; (16) S. repens; (17) P. stipularis; (18) Thesium sp.; (19) L. perenne; (20) R. acetosella. Kobresia meadows: (21) K. myosuroides; (22) P. nivea; (23) Minuartia verna; (24) Carex argunensis; (25) T. alpinum. Arctic pioneer communities: (26) Cerastium beeringianum; (27) Minuartia rubella; (28) M. arctica; (29) Papaver sect. Scapiflora; (30) Draba sp.

snow cover, late snowmelt, shortened growing season, and lowered soil temperature in summer that is additionally decreased by melting snow (Dierßen, 1996).

\section{Discussion and conclusions}

The macrofossil composition of permafrost sediments from the sequence Mamontovy Khayata reveals that a complex of aquatic, littoral, meadow and steppe associations existed among high arctic plant communities at today's Bykovsky Peninsula, reflecting a wide variety of habitat conditions during the last cold stage. Several authors have suggested that diverse vegetation mosaics must have existed in Beringia (Elias et al., 1997; Goetcheus and Birks, 2001; Guthrie, 1990; Yurtsev, 2001), however, in a composition without modern analogues (Goetcheus and Birks, 2001). The assumption of mosaic-like distributed palaeovegetation bases on the concept of "actualism," which is the foundation of palaeo-bioindication. The landscape is never uniform, and consequently depending on the availability of radiation, moisture, nutrients and competition, vegetation is always unevenly distributed. When we, however, apply the actualism principle consequently, and assume that the autecological requirements of plant species did not change considerably during the late Quaternary, we must imply the same for the synecological behaviour of those plants, because plants with resembling ecology occur together, now and in the past. Therefore, we assumed that there must be modern analogues of Beringia's cold-stage vegetation, even though much more restricted geographically today. Thus, we focused on the xerophilous vegetation complexes described as glacial relicts in central and northeast Yakutia by Yurtsev $(1982,2001)$. For the first time, we could show that characteristic components of the xerophyte relict vegetation, including steppe plants, really existed in arctic Beringia during the last cold stage.

Arguable macrofossil finds of steppe indicators by Kienast et al. (2001) and Zazula et al. (2003) in the vicinity of Beringia's shelf-land offered already valuable clues. Kienast et al. (2001) found individual macroremains of the steppe plants A. obovatum and Carex cf. stenophylla (in fact the closely related east Siberian vicar $C$. duriuscula) in Ice Complex sediments at the Taymyr Peninsula in species spectra that are predominantly composed of arctic pioneer plants. The steppe Crassulaceae, Orostachys spinosa, was probably misidentified. Its identification shall be checked later by DNA analysis. In the Yukon Territory, Zazula et al. (2003) listed taxa of potential steppe indicators (Draba, Cerastium, Carex, Artemisia, Juncaceae, Potentilla, Ranun- 


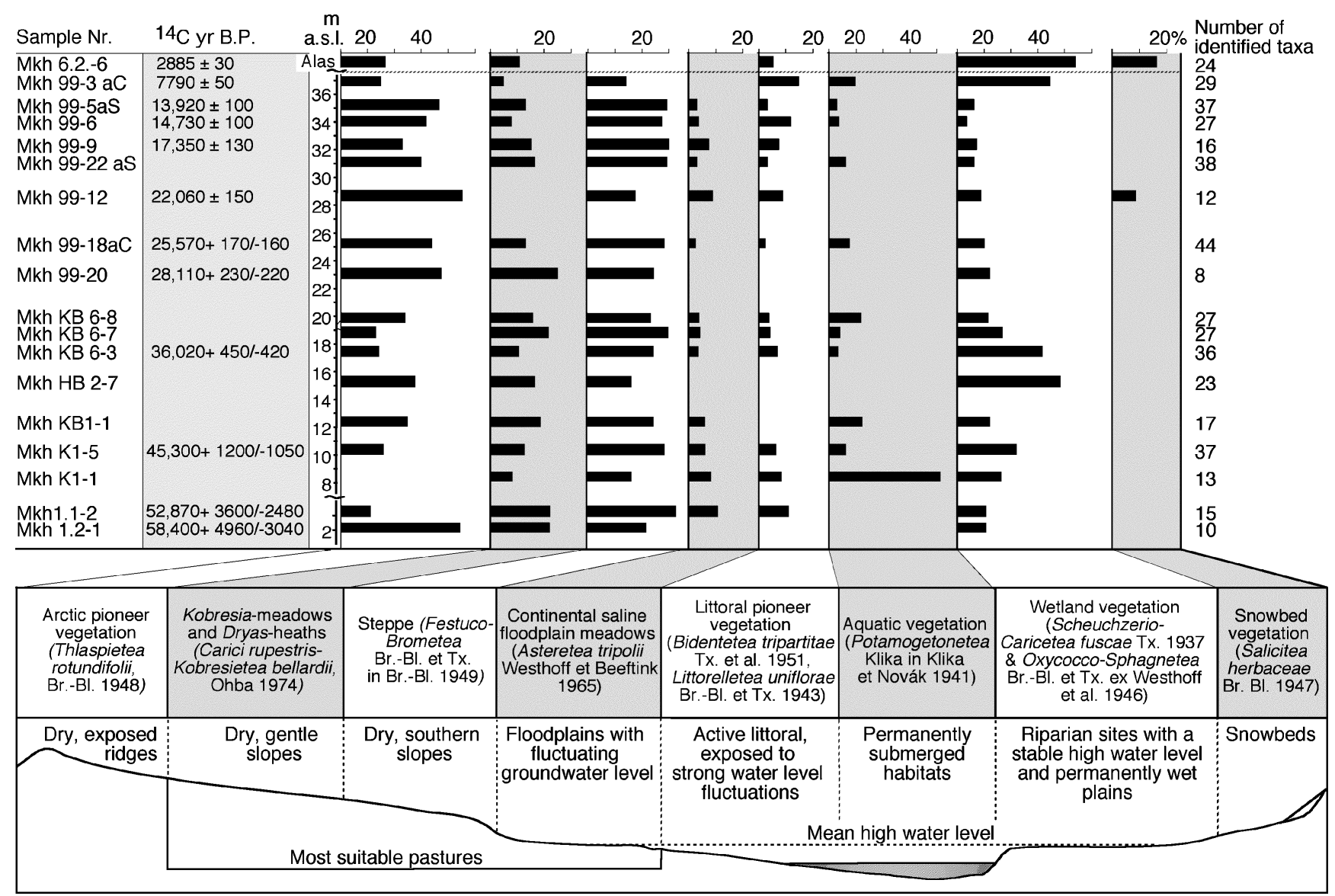

Figure 7. Representation of the reconstructed syntaxa for the macrofossil assemblages of the site Mamontovy Khayata and idealized distribution patterns of plant communities with respect to the local topography.

culus, Papaver, Silene) that are, however, widely distributed in arctic tundras and even in arctic deserts today or occur at specific habitats rather independent on macroclimate (Elymus). For example, Elymus arenarius is characteristic of sand dunes in north Alaska (Walker et al., 2001). The identification of Artemisia frigida, that is the most indicative steppe species in Zazula et al. (2003), is, according to the photo in that paper hardly reproducible. Androsace septentrionalis, the other steppe indicator in that study, may occur extrazonally in arctic and subarctic areas today and occurs, for instance, on sandy slopes in the Lena River delta at $72^{\circ} \mathrm{N}$ (Kienast and Tsherkasova, 2001).

The reconstructed vegetation complex of the last cold stage differs substantially from the Holocene vegetation at the Bykovsky Peninsula. All plant communities described for the last cold stage are absent or rare during the Holocene (Fig. 7). In contrast to the reconstructed diverse cold-stage vegetation, the Holocene tundra is almost uniform.

We consider two factors to explain the reconstructed features of the last cold-stage vegetation and its difference from modern arctic tundra: moisture availability and summer warmth. Mkh's cold-stage vegetation indicates that moisture rather than temperature acted restricting on vegetation. The high percentage of Pediastrum and Botryococcus algae in Mkh pollen and spore spectra (Andreev et al., 2002) and the presence of aquatic and littoral taxa in the macrofossil assemblage indicate that the deposits were accumulated in shallow water. Although an overrepresentation of wet place indicators is probable, the late Pleistocene vegetation complex indicates arid climate conditions. The pioneer character of aquatic and littoral vegetation, indicating shrinking or desiccation of shallow lakes and small pools, suggests dry summers during the last cold stage. The former existence of floodplain meadows and the halotolerance of many identified species also suggest large seasonal groundwater fluctuations and consequently strong evaporation under an arid climate. In particular, the presence of Puccinellia tenuiflora is indicative of salt accumulation in the topsoil horizon, caused by high evaporation of groundwater. Under warm and dry summer conditions, permafrost supports salt accumulation by damming groundwater and supplying moisture and solutes (Yelovskaya et al., 1966). Abundant macrofossils of steppe and droughtresistant arctic plants confirm arid conditions. Macrofossils of taxa from permanently wet habitats (like mires) were found only sporadically in last cold-stage sediments, mainly from the Middle Weichselian Interstade, dated about $48,000-35,000{ }^{14} \mathrm{C}$ yr B.P. (Fig. 7). In contrast, the Holocene macroremains indicate steadily wet environments as a result of increased oceanic influence and atmospheric humidity. 
The paludification happened, however, successive. Whereas sporadic steppe indicators persisted in the early Holocene, they disappeared completely before $22900{ }^{14} \mathrm{C}$ yr B.P.

The macrofossils of some boreal aquatics in the Mkh sequence allow to make some conclusions about summer temperatures. Aquatic plants are regarded as excellent temperature indicators (Iversen, 1954). In contrast to terrestrial warmth indicators, which may occur extrazonally at south facing slopes, aquatics reflect the zonal thermal regime independent on topography and altitude of the sun (Iversen, 1954). Furthermore, they indicate average summer temperatures, buffered by the thermal capacity of lake water. Aquatics are also able to occupy new habitats extremely quickly after establishment of favorable conditions (Elias et al., 1997). At the study site, mean July temperatures above $12^{\circ} \mathrm{C}$ can be inferred for most of the last cold stage, based on modern climate values at the northernmost distribution limit of the boreal species Potamogeton vaginatus in eastern Siberia, according to Krasnoborov (1988). At about $48,000{ }^{14} \mathrm{C}$ yr B.P. and around $35,000{ }^{14} \mathrm{C}$ yr B.P., the occurrence of the temperate aquatic plant Callitriche hermaphroditica is reliable evidence of mean summer temperatures higher than $12^{\circ} \mathrm{C}$. Moreover, the finding of the steppe taxon Thesium in the sediments dated to $48,000{ }^{14} \mathrm{C}$ yr B.P. suggests July temperatures $>15^{\circ} \mathrm{C}$ then. Some of the aquatics recorded in the deposits were also found in cold-stage sediment cores from the shelves of the Chukchi and Bering Seas in central Beringia (Elias et al., 1997). Warm summers during the Middle Weichselian Interstade are suggested by other bioindicators as well. Periods of prominent aridity and summer temperature higher than present are implied by steppe insects between about $48,000-35,000$ and $18,000-12,500{ }^{14} \mathrm{C}$ yr B.P. (Kuzmina, 2001; Sher et al., 2001) as well as by pollen spectra between about 48,000 and $33,000{ }^{14} \mathrm{C}$ yr B.P. (Andreev et al., 2002).

The macrofossil spectra do, however, not reflect increased summer temperatures during the entire late Pleistocene. There are samples, especially the samples dated to $\sim 58,000,28,100$ and $22,100{ }^{14} \mathrm{C}$ yr B.P., containing no solid warmth indicators but characterized by dominating arctic pioneer species and decreased floristic diversity (Fig. 7). Although taphonomical biases cannot be excluded, these results could point to fluctuating thermal conditions within the last cold stage. A cooling effect of local mountain glaciers in the Verkhoyansk Mountains is conceivable. The composition of Mkh's insect spectra (Kuzmina, 2001; Sher et al., 2001) suggests summer temperatures lower than present between about 25,000 and $18,000{ }^{14} \mathrm{C}$ yr B.P. (Kuzmina, 2001; Sher et al., 2001). High concentrations of Selaginella rupestris spores in the pollen spectra between about 26,000 and $16,000{ }^{14} \mathrm{C}$ yr B.P. indicate denuded and disturbed soils and dry conditions and were also interpreted as characteristic of cold and dry climate (Andreev et al., 2002). But, according to our results the north Siberian summers continued to be warmer than present during the most part of the Late Weichselian cold stage. Steppe plants reached their highest diversity and abundance, and boreal warmth indicators, such as Potamogeton vaginatus, still occurred, although more sporadically, likely due to further increased aridity and the disappearance of aquatic habitats (Fig. 7).

Species of Kobresia meadows and arctic pioneer communities are extremely cold-resistant and characteristic of thin or lacking snow cover. Thus, they suggest low snow accumulation and winters colder than present throughout the whole last cold stage. This assumption is consistent with results of an isotope record from Mkh ice wedges (Meyer et al., 2002), showing that during the last cold stage, stable heavy isotopes $\left({ }^{18} \mathrm{O},{ }^{2} \mathrm{H}\right)$ in winter precipitation water reached low values, which are correlated with very cold winter temperatures. Macrofossils of Kobresia meadows and arctic pioneer communities were also proven for the last cold stage at the Seward Peninsula in east Beringia (Goetcheus and Birks, 2001) and at the Taymyr Peninsula (Kienast et al., 2001).

Seasonal temperature gradients much larger than at present, and the negative summer water balance during the last cold stage point to a climate more continental than today. This implication is consistent with the late Pleistocene sea level lowering and the associated extension of the continent by several hundred kilometers north of the study site (Fig. 1). The reconstructed climatic changes can be better understood by comparing modern climate data from the coastal meteorological station Tiksi with the inland one in Yansk $\left(68^{\circ} 26^{\prime} \mathrm{N}, 134^{\circ} 47^{\prime} \mathrm{E}\right)$, situated $300 \mathrm{~km}$ south of the Bykovsky Peninsula (Fig. 1), and reflecting continental climate. In Yansk, the mean July temperature is $14^{\circ} \mathrm{C}, 7^{\circ} \mathrm{C}$ higher than in Tiksi, whereas annual $\left(-14.5^{\circ} \mathrm{C}\right)$ and January $\left(-44^{\circ} \mathrm{C}\right)$ temperatures are lower than in Tiksi by $1^{\circ}$ and $11^{\circ} \mathrm{C}$, respectively (http://www.meteo.infospace.ru/). The extremely continental climate in the Yansk area is apparently favorable for the preservation of relic steppe communities, which occur there (Fig. 1). It may reflect the similarity of modern climate and vegetation there with the climate and vegetation during the last cold stage on the Bykovsky Peninsula.

If summer temperatures were higher than $12^{\circ} \mathrm{C}$, why are there no macrofossils of boreal trees at the Bykovsky Peninsula in sediments from the last cold stage? The probable reasons are the special features of continentality: aridity and severe winters. Today, the mean annual precipitation is around $200 \mathrm{~mm}$ at the study site. Even if we assume that the precipitation would have been the same during the last cold stage, the increased evaporation in consequence of warmer summers would shift the water balance towards aridity. Due to extreme continentality during the Weichselian, we must, however, assume even lower precipitation than today. Aridity is well indicated in the macrofossil assemblages by the presence of salt indicators, steppe plants and indicators of strong groundwater fluctuations. The relict steppe vegetation in Yakutia 
occurs at south exposed, well-drained, dry and warm extrazonal sites within the taiga zone (Yurtsev, 1982, 2001). Trees are limited in these areas to north facing slopes, depressions and ravines, where water accumulates and evaporation is decreased. Thus, boreal trees require relatively warm, but more important, moist (mesic) conditions as well, as is apparent from the northward shift of the treeline in Siberia during the early Holocene (Kremenetski et al., 1998; MacDonald et al., 2000), when summers were still relatively warm but precipitation already increased (according to Mkh macrofossils in the $7800{ }^{14} \mathrm{C}$ yr old sample). Increased precipitation results in a thicker snow cover, which protects plants with aboveground renewal buds, such as tree seedlings or dwarf shrubs, against the effects of very low winter temperatures. In contrast, low snow cover, snow abrasion and grazing all favor plants with renewal buds close to or below the ground, such as grasses. The Biome 4 vegetation model suggests that a snow thickness of less than $15 \mathrm{~cm}$ results in the predominance of grasses in the arctic (Kaplan, 2001). The thin snow cover could explain how large populations of mammals could survive the long arctic winters during the last cold stage (Andreev et al., 2004). Because of lacking snow cover, the nutrient rich grasses and forbs would have been available for herbivores, preserved quasi freeze-dried throughout the winter.

The absence of boreal trees can be ascribed, to a certain degree, to the disturbing influence of megaherbivores (Owen-Smith, 1988). The Mkh plant species spectra show that cold-stage vegetation in northeastern Siberia was at least locally productive enough to support large grazers and consequently hunters, who occurred roughly $200 \mathrm{~km}$ to the east at the Yana RHS Site $\left(70^{\circ} 43^{\prime} \mathrm{N}\right.$, $135^{\circ} 25^{\prime} \mathrm{E}$ ) at $\sim 27,000{ }^{14} \mathrm{C}$ yr B.P. (Pitulko et al., 2004). The numerous mammal bones from Mkh reflect a rich wildlife at the Bykovsky Peninsula during the last cold stage (Kuznetsova et al., 2003). Kobresia meadows, steppe communities and especially floodplain meadows can be classified as possible pastures for large herbivores. Floodplain meadows are the most productive vegetation type in central Yakutian alas regions today, intensively used for pastures and haymaking. The abundant occurrence of $C$. duriuscula in the fossil assemblages is particularly interesting in this context because that species indicates degradation of steppe vegetation by overgrazing and trampling (Hilbig, 1995).

The available macrofossil records do not allow the conclusion that the described last cold-stage vegetation complex was widespread over whole northern Siberia and the exposed arctic shelves. For the time being, the Mkh macrofossil record must be considered as local vegetation. It is difficult to say whether the high percentage of arctic (or alpine) pioneer species is characteristic of Beringia's lowland vegetation. It is also possible that remains of these taxa were transported from the foothills of the Kharaulakh Range to the Bykovsky Peninsula during snow melt and are consequently of rather alpine origin. Future investigations of different permafrost sequences around the Laptev Sea coasts shall answer this question.

\section{Acknowledgments}

We thank A. Sher for sampling, H. Meyer for making available plant remains enclosed in ice wedges, D.H. Mai and J.P. Pals for help in macrofossil identification, the Museum for Natural History at the Humboldt University, Berlin, for use of the carpological collection, P.A. Gogoleva for making available Siberian reference seeds and support in sampling reference material, H. Joosten, H. Henschel and H.H. Birks for helpful comments on earlier versions and the Federal Ministry of Education and Research, Germany, for financial support.

\section{References}

Aalto, M., 1970. Potamogetonaceae fruits: I. Recent and subfossil endocarps of the Fennoscandian species. Acta Botanica Fennica 88, $1-85$.

Abott, R.J., Brochmann, C., 2003. History and evolution of the Arctic Flora: in the footsteps of Eric Hultén. Molecular Ecology 12, 299-313.

Adams, M., 1807. Some account of a journey to the frozen sea, and of the discovery of the remains of a mammoth. Philosophical Magazine 29, $141-143$.

Anderberg, A.-L., 1994. Atlas of small fruits of Northwest-European plant species (...) with morphological descriptions: Part 4. ResedaceaeUmbelliferae. Swedish Museum of Natural History, Stockholm.

Anderson, P.M., Bartlein, P.J., Brubaker, L.B., 1994. Late Quaternary history of tundra vegetation in northwestern Alaska. Quaternary Research 41, 306-315.

Andreev, V.N., Galaktionova, T.F., 1981. Relict Tundra-Steppe groupings in the tundra of the lower Kolyma. Vegetation of Yakutia and its protection. Yakutian agency of the Siberian division of the Academy of Sciences of the USSR, pp. 26-36. In Russian.

Andreev, A.A., Schirrmeister, L., Siegert, C., Bobrov, A.A., Demske, D., Seiffert, M., Hubberten, H.-W., 2002. Paleoenvironmental changes in northeastern Siberia during the Late Quaternary-evidence from pollen records of the Bykovsky Peninsula. Polarforschung 70, 13-25.

Andreev, A.A., Tarasov, P.E., Klimanov, V.A., Melles, M., Lisitsynae, O.M., Hubberten, H.-W., 2004. Vegetation and climate changes around the Lama Lake, Taymyr Peninsula, Russia during the late Pleistocene and holocene. Quaternary International 122, 69-84.

Beijerinck, W., 1947. Zadenatlas der Nederlandsche Flora. Veenmann and Zonen, Wageningen.

Berggren, G., 1969. Atlas of seeds and fruits of Northwest-European plant species with morphological descriptions: Part 2. Cyperaceae. Swedish Natural Science Research Council, Stockholm.

Berggren, G., 1981. Atlas of seeds and fruits of Northwest-European plant species with morphological descriptions: Part 3. Salicaceae-Cruciferae. Swedish Natural Science Research Council, Stockholm.

Birks, H.J.B., Birks, H.H., 1980. Quaternary ecology. Edward Arnold, London.

Birks, H.H., Birks, H.J.B., 2000. Future of pollen analysis must include plant macrofossils. Journal of Biogeography 27, 31-35.

Bobrov, A.A., Andreev, A.A., Schirrmeister, L., Siegert, C., 2004. Testate amoebae (Protozoa: Testacea) as bioindicators in the late quaternary deposits of the Bykovsky Peninsula, Laptev Sea, Russia. Palaeogeography, Palaeoclimatology, Palaeoecology 209, 165-181. 
Böcher, T.W., 1954. Oceanic and continental vegetational complexes in Southwest Greenland. Meddelelser Om Grønland 148 (1), 1-336 (Copenhagen).

Borisov, A.A., 1965. Palaeoclimates of the Territories of the USSR Moscow-Leningrad, Nauka. In Russian.

Cappers, R.T.J., 1993. The identification of potamogetonaceae fruits found in the Netherlands. Acta Botanica Neerlandica 42 (4), 447-460.

CAVM Team, 2003. Circumpolar Arctic vegetation map. Scale 1:7,500,000. Conservation of Arctic Flora and Fauna (CAFF) Map No. 1. U. S. Fish and Wildlife Service, Anchorage, Alaska.

Clark, P.U., Mix, A.C., 2002. Ice sheets and sea level of the last glacial maximum. Quaternary Science Reviews 21, 1-7.

Clark, P.U., Clague, J.J., Curry, B.B., Dreimanis, A., Hicock, S.R., Miller, G.H., Berger, G.W., Eyles, N., Lamothe, M., Miller, B.B., Mott, R.J., Oldale, R.N., Stea, R.R., Szabo, J., Thorleifson, L.H., Vincent, J.-S., 1993. Initiation and development of the Laurentide and Cordilleran ice sheets following the last interglaciation. Quaternary Science Reviews 12 (2), 79-114

Clark, P.U., Alley, R.B., Pollard, D., 1999. Northern hemisphere ice-sheet influences on global climate change. Science 286, 1104-1111.

Cwynar, L.C., Ritchie, J.C., 1980. Arctic steppe-tundra: a Yukon perspective. Science 208, 1375-1377.

Dierßen, K., 1996. Vegetation of North Europe. Eugen Ulmer, Stuttgart. In German.

Drachev, S.S, Savostin, L.A., Groshev, V.G., Bruni, I.E., 1998. Structure and geology of the Laptev Sea, eastern Russian arctic. Tectonophysics 298, 357-393.

Egorova, T.V., 1999. The Sedges (Carex L.) of Russia and Adjacent States (within the Limits of the former USSR). Missouri Botanical Garden Press, St. Louis. In Russian.

Elias, S.A., Short, S.K., Birks, H.H., 1997. Late Wisconsin environments of the Bering land bridge. Palaeogeography, Palaeoclimatology, Palaeoecology 136, 293-308.

FAO-UNESCO, 1988. Soil map of the world, revised legend. Food an Agriculture Organization of the United Nations, Rom.

Frenzel, B., Pécsi, M., Velichko, A.A. (Eds.), 1992. Atlas of palaeoclimates and palaeoenvironments of the Northern Hemisphere. Late PleistoceneHolocene. Gustav Fischer, Stuttgart.

Glück, H., 1936. In: Pascher, A. (Ed.), The fresh water Flora of Central Europe, vol. 15. Gustav Fischer, Jena. In German.

Goetcheus, V.G., Birks, H.H., 2001. Full-glacial upland tundra vegetation preserved under tephra in the Beringia National Park, Seward Peninsula, Alaska. Quaternary Science Reviews 20, 135-147.

Grigoriev, M.N., 1993. Cryomorphogenesis of the Lena River Mouth Area SO AN SSSR, Yakutsk. In Russian.

Guthrie, R.D., 1990. Frozen fauna of the Mammoth Steppe. University of Chicago Press, Chicago.

Guthrie, R.D., 2001. Origin of the mammoth steppe: a story of cloud cover, woolly mammal tooth pits, buckles, and inside-out Beringia. Quaternary Science Reviews 20,549-574.

Hilbig, W., 1995. The vegetation of Mongolia. SPB Academic Publishing, Amsterdam.

Hulten, E., 1937. Outline of the history of arctic and boreal biota during the quaternary period. Bokförlags Aktiebolaget Thule, Stockholm.

Ivanov, M.S., Katasonova, E.G., 1978. Pecularities of cryolithogenic deposits of the Muostakh Island. In: Anisimov, N.P., Katasonova, E.G. (eds.), Geocryologic and hydrogeologic research in Yakutia, Permafrost Institute, SO AN SSSR, Yakutsk, 12-25. In Russian.

Iversen, J., 1954. The late-glacial Flora of Denmark and its relation to climate and soil. Danmarks Geologiske Undersøegelse: II. Række 80, $88-118$.

Iversen, J., 1973. The development of Denmark's nature since the Last Glacial. Danmarks Geologiske Undersøgelse V, Copenhagen.

Jessen, K., 1955. Key to subfossil potamogeton. Botanisk Tidsskrift 52 , $1-7$.

Kageyama, M., Peyron, O., Pinot, S., Tarasov, P., Guiot, J., Joussaume, S., Ramstein, G., 2001. The last glacial maximum climate over Europe and western Siberia: a PMIP comparison between models and data. Climate Dynamics $17,23-43$.

Kaplan, J.O., 2001. Geophysical Applications of Vegetation Modelling. $\mathrm{PhD}$ Thesis, Lund University, Lund.

Katz, N.Ya., Katz, S.V., Kipiani, M.G., 1965. Atlas and keys of fruits and seeds occurring in the quaternary deposits of the USSR. Nauka, Moscow. In Russian.

Kienast, F., Tsherkasova, J., 2001. Comparative botanical recent-studies in the Lena-River Delta. Reports on Polar and Marine Research 388, $24-44$

Kienast, F., Siegert, C., Dereviagin, A., Mai, D.-H., 2001. Climatic implications of late quaternary plant macrofossil assemblages from the Taymyr Peninsula, Siberia. Global and Planetary Change 31, $265-281$.

Körber-Grohne, E., 1964. Bestimmungsschlüssel für subfossile JuncusSamen und Gramineen-Früchte. August Lax, Hildesheim.

Kozhevnikov, Yu., Ukraintseva, V.V., 1997. Arguments for and against a Pleistocene tundra-steppe. Polar Geography 21, 51-69.

Krasnoborov, I.M. (Ed.), 1998. Flora Sibiri, Lycopodiaceae-Hydrocharitaceae. Nauka, Novosibirsk.

Kremenetski, C.V., Sulerzhitsky, L.D., Hantemirov, R., 1998. Holocene history of the northern range limits of some trees and shrubs in Russia. Arctic and Alpine Research 30 (4), 317-333.

Kutzbach, J.E., Guetter, P.J., Behling, P., Selin, R., 1993. Simulated climatic changes: results of the COHMAP climate-model experiments. In: Wright Jr., H.E., et al., (Eds.), Global Climates Since the Last Glacial Maximum. University of Minnesota Press, Minneapolis, pp. 24-93.

Kuzmina, S., 2001. Quaternary insects of coastal lowlands in Yakutia. Dissertation. Institute of Paleontology. RAS, Moscow. In Russian.

Kuznetsova, T.V., Sulerzhitsky, L.D., Andreev, A.A., Siegert, C., Schirrmeister, L., Hubberten, H.-W., 2003. Influence of late quaternary paleoenvironmental conditions on the distribution of mammals in the Laptev Sea region. Occasional Papers in Earth Sciences 5, 58-60.

Lambeck, K., Chappell, J., 2001. Sea level change through the last glacial cycle. Science 292, 679-686.

MacDonald, G.M., Velichko, A.A., Kremenitski, C.V., Borisova, O.K., Goleva, A.A., Andreev, A.A., Cwynar, L.C., Riding, R.T., Forman, S.L., Edwards, T.W.D., Aravena, R., Hammarlund, D., Szeicz, J.M., Gattaulin, V.N., 2000. Holocene treeline history and climate change across northern Eurasia. Quaternary Research 53, 302-311.

Marincovich, L., Gladenkov, A.Y., 1999. Evidence for an early opening of the Bering Strait. Nature 397, 149-151.

Meusel, H., Jäger, E., Rauschert, S., Weinert, E., 1978. Comparative chronology of the Central European Flora, vol. II. Gustav Fischer, Jena. In German.

Meyer, H., Dereviagin, A., Siegert, C., Hubberten, H.-W., 2002. Palaeoclimate studies on Bykovsky Peninsula, North Siberia-hydrogen and oxygen isotopes in ground ice. Polarforschung 70, 37-51.

Mirkin, B.M., Gogoleva, P.A., Kononov, K.E., 1985. The vegetation of central Yakutian Alases. Folia Geobotanica et Phytotaxonomica 20, 345-395.

Nehring, A., 1890. Über Tundren und Steppen der Jetzt- und Vorzeit unter besonderer Berücksichtigung ihrer Fauna (About Tundras and Steppes in former and present times with special consideration of their Fauna). F. Dummer, Berlin. In German.

Nimis, P.L., Malyshev, L.I., Bolognini, G., Friesen, N., 1998. A multivariate phytogeographic analysis of plant diversity in the Putorana Plateau (N. Siberia). Opera Botanica 163, 1-72.

Orlova, L.A., Kuzmin, Ya.V, Volkova, V.S., Zolnikov, I.D., 2000. Mammoth (Mammuthus primigenius Blum.) and the early human in Siberia: coupled analysis of distribution areas based on radiocarbon data). In: Vaganov, E.A., Derevyanko, A.P., Zykin, V.S., Markin, S.V. (Eds.), Problems of the Reconstruction of Climate and Nature in Siberia During the Middle Holocene and Pleistocene. Institute of Archaeology and Ethnography Press, SO RAN, Novosibirsk. 383-412. In Russian.

Owen-Smith, R.N., 1988. Megaherbivores: the influence of very large body size on ecology. Cambridge University Press, Cambridge. 
Pitulko, V.V., Nikolsky, P.A., Girya, E.Yu., Basilyan, A.E., Tumskoy, V.E., Koulakov, S.A., Astakhov, S.N., Pavlova, E.Yu., Anisimov, M.A., 2004. The Yana RHS site: humans in the arctic before the last glacial maximum. Science 303, 52-56.

Ritchie, J.C., 1984. Past and present vegetation of the Far Northwest of Canada. University of Toronto Press, Toronto.

Schirrmeister, L., Siegert, C., Kuznetsova, T., Kuzmina, S., Andreev, A.A., Kienast, F., Meyer, H., Bobrov, A.A., 2002a. Paleoenvironmental and paleoclimatic records from permafrost deposits in the arctic region of Northern Siberia. Quaternary International 89, 97-118.

Schirrmeister, L., Siegert, Ch., Kunitzky, V.V., Grootes, P., Erlenkeuser, H., 2002 b. Late quaternary ice rich permafrost sequences as a palaeoenvironmental archive for the Laptev sea region in northern Siberia. International Journal of Earth Sciences 91, 154-167.

Sher, A., Parmuzin, I., Bortsov, A., 2000. Ice complex on the Bykovsky Peninsula. In: Rachold, V. (Ed.), Expeditions in Siberia in 1999, Reports on polar research, vol. 354, pp. 169-182.

Sher, A.V., Kuzmina, S.A., Kuznetsova, T.V., Sulerzhitsky, L.D., Schirrmeister, L., Siegert, C., Andrrev, A.A., Grootes, P.M., Kienast, F., Hubberten, H.W., 2001. The last glacial environment in the unglaciated arctic shelf land. EUG XI-Journal of Conference Abstracts 6 (1), 207.

Siegert, Ch., Schirrmeister, L., Babiy, O., 2002. The sedimentological, mineralogical, and geochemical composition of late Pleistocene deposits from the Ice Complex on the Bykovsky peninsula, Northern Siberia. Polarforschung 70, 3-11.

Sulerzhitsky, L.D., Romanenko, F.A., 1997. Age and distribution of the "mammoth" fauna of the polar region of Asia (radiocarbon dating results). Cryosphera Zemli 1 (2), 12-19 (In Russian).

Svendsen, J.I., Astakhov, V.I., Bolshiyanov, D.Yu., Demidov, I., Dowdeswell, J.A., Gataullin, V., Hjort, C., Hubberten, H.W., Larsen, E., Mangerud, J., Melles, M., Möller, P., Saarnist, M., Siegert, M.J., 1999. Maximum extent of the Eurasian ice sheets in the Barents and Kara Sea region during the Weichselian. Boreas 28, $234-242$.

Svendsen, J.I., Alexanderson, H., Astakhov, V.I., Demidov, I., Dowdeswell, J.A., Funder, S., Gataullin, V., Henriksen, M., Hjort, C., HoumarkNielsen, M., Hubberten, H.-W., Ingólfsson, Ó., Jakobsson, M., Kjær, K.H., Larsen, E., Lokrantz, H., Lunkka, J.P., Lyså, A., Mangerud, J., Matiouchkov, A., Murray, A., Möller, P., Niessen, F., Nikolskaya, O.,
Polyak, L., Saarnisto, M., Siegert, C., Siegert, M.J., Spielhagen, R.F., Stein, R., 2004. Late quaternary ice sheet history of northern Eurasia. Quaternary Science Reviews 23, 1229-1271.

Tugarinov, A.Ya., 1929. Origin of the Arctic Fauna. Priroda. 7-8. 653-680 (In Russian).

Vartanyan, S.L., Garutt, V.E., Sher, A.V., 1993. Holocene dwarf mammoths from Wrangel island in the Siberian Arctic. Nature 362, 337-340.

Velichko, A.A., 1984. Late Pleistocene spatial palaeclimatic reconstructions. In: Velichko, A.A. (Ed.), Late Quaternary Environments of the Soviet Union. University of Minnesota Press, Minneapolis, pp. $261-285$.

Walker, M.D., Walker, D.A., Everett, K.R., Short, S.K., 1991. Steppe vegetation on south-facing Slopes of Pingos, central arctic coastal plain. Arctic and Alpine Research 23 (2), 170-188.

Walker, D.A., Bockheim, J.G., Chapin III, F.S., Eugster, W., Nelson, F.E., Ping, C.L., 2001. Calcium-rich tundra, wildlife, and the "Mammoth Steppe". Quaternary Science Reviews 20, 149-163.

Weber, H.E., Moravec, J., Theurillat, J.-P., 2000. International code of phytosociological nomenclature. Third edition. Journal of Vegetation Sciences 11, 739-768.

Wetterich, S., Schirrmeister, L., Pietrzeniuk, E., submitted for publication, Freshwater ostracodes in Quaternary permafrost deposits from the Siberian Arctic. Journal of Paleolimnology.

Willerslev, E., Hansen, A.J., Binladen, J., Brand, T.B., Gilbert, M.T.P., Shapiro, B., Bunce, M., Wiuf, C., Gilichinsky, D.A., Cooper, A., 2003. Diverse plant and animal genetic records from Holocene and Pleistocene sediments. Science 300, 791-795.

Yelovskaya, L.G., Konorovsky, A.K., Savinov, D.D., 1966. Salt-Rich Soils above Permafrost (Kryosols) in Central Yakutia. Nauka, Moscow. In Russian.

Yurtsev, B.A., 1982. Relics of the xerophyte vegetation of Beringia in Northeastern Asia. In: Hopkins, D.M., Matthews Jr., J.V., Schweger, C.E., Young, S.B. (Eds.), Paleoecology of Beringia. Academic Press, New York, pp. 157-177.

Yurtsev, B.A., 2001. The Pleistocene "Tundra-Steppe" and the productivity paradox: the landscape approach. Quaternary Science Reviews 20, $165-174$.

Zazula, G.D., Frese, D.G., Schweger, C.E., Mathewes, R.W., Beaudoin, A.B., Telka, A.M., Harington, C.R., Westgate, J.A., 2003. Ice-age steppe vegetation in east Beringia. Nature 423, 603. 